\title{
Socio-Environmental Aspects on Solid Waste, Air Pollution, Water and Forest Conservation Surrounding Geothermal Area: A Success Story
}

\author{
Dewi Permatasari, Eko Yuniarto, Wahyu Somantri, and Dedi Supriadi
}

\begin{abstract}
This paper aims to introduce a company successfulness on environmental management of geothermal industry by enhancing community around geothermal power operation area. Toward improvement of environmental compliance effort, corporate management committed to support the Strategic Programs for environmental and social aspect. Methods on this paper underlined the innovation to integrate environmental behaviorism within social life. It has done by bring together the community, government, and company to persuade public participation on strategic programs that have been successfully held.

The voluntary program was "Education of Energy Saving and Climate Change for 50 Students", which is strongly connected to energy efficiency and air pollution aspect. It was then followed by the other socio-environmental aspects about the introduction of municipal solid and hazardous waste for "Pelag Local Community". On biodiversity conservation, 25,000 endemic crops were planted in Kamojang Forest, and then Collaborative Action to Conserve the Cikaro Stream was completing the program that involves public participation on water conservation. This entire distinguished program held in 2014 with emphasized purpose is to preserve and protect the environment through community development.

To sum up, successful programs shows that collaboration among stakeholder can improve the social values in order to conserve the environment. It is also periodically reported to the Ministry of Environment under Environmental Compliance Assessment, PROPER.
\end{abstract}

Index Terms-Socio-environment, strategic programs, geothermal area, PROPER.

\section{INTRODUCTION}

Geothermal energy can produce a sustainable electricity generation, as Indonesia has the largest geothermal prospect through ring of fire pathways. Geothermal energy development has added value, such for environment aspects, local community development, etc. [1]-[4]. It has proved that several geothermal industries, in Indonesia, reach the most prestigious achievement on Company Performance Assessment Program on Environmental Compliance, as commonly known as PROPER. PROPER, assessed every

Manuscript received June 9, 2014; revised October 12, 2014. This program was supported in part by the PT. Indonesia Power Corporation and PT. Indonesia Power - Generation Business Unit of Kamojang.

Dewi Permatasari was with Institut Teknologi Bandung, Bandung, 40132 Indonesia. She is now with PT. Indonesia Power - GBU Kamojang, West Java Province, 44101 Indonesia (e-mail: dewi16permatasari@ gmail.com).

Eko Yuniarto, Wahyu Somantri, and Dedi Supriadi are with PT. Indonesia Power - GBU Kamojang, West Java Province, 44101 Indonesia (e-mail:

eko.yuniarto@indonesiapower.co.id, wahyu.somantri@indonesiapower.co.id,supriadi@indonesiapower.co.id). period from Ministry of Environment (MoE) Indonesia, currently works under Minister of Environment Regulation No. 06/ 2013 [5].

PT. Indonesia Power - Generation Business Unit (GBU) of Kamojang is one of business unit under PT. Indonesia Power Corporation, a subsidiary of State Electricity Company (PT. PLN Persero). GBU Kamojang located in West Java Province, one of the largest geothermal electricity operations in Indonesia with reserve about 3,290 MW [6]. It operates three location of geothermal power plant, as depicted on Fig. 1, consists of Kamojang (Unit 1, 2, and 3), Darajat (Unit 1), and Gunung Salak (Unit 1, 2, and 3).

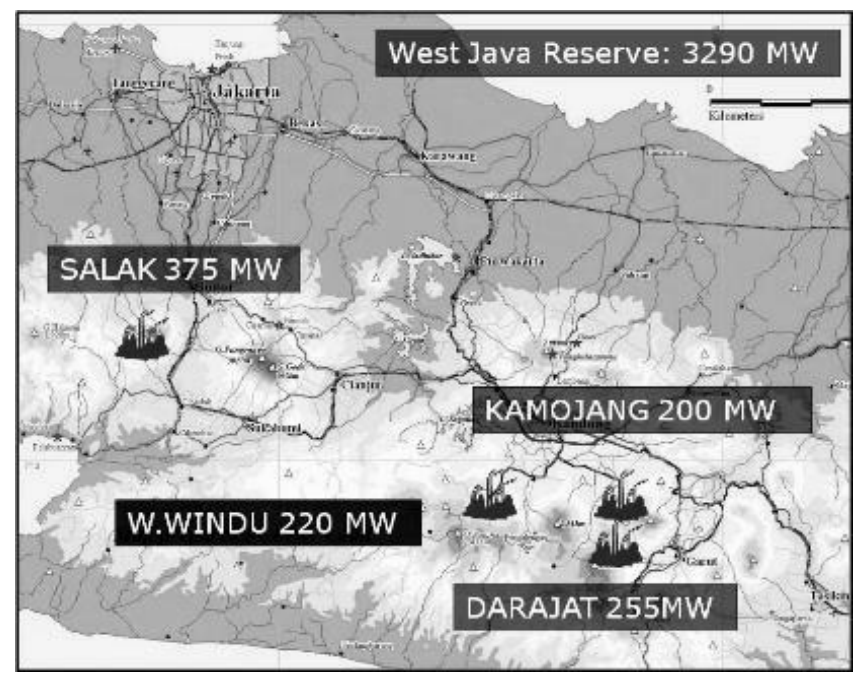

Fig. 1. Geothermal electricity generation in West Java Province, Indonesia [5].

GBU Kamojang operates 140 MW Kamojang Power Plant, whereas the other 60 MW operated by PT. Pertamina Geothermal Energy; GBU Kamojang operates 55 MW Darajat and 180 MW Gunung Salak Power Plant, whereas 200 MW Darajat and 195 MW Gunung Salak operated by Chevron. There is also $220 \mathrm{MW}$ Wayang Windu Geothermal Power Plant, operated by Star Energy.

Geothermal Power Plant Unit of Kamojang-Darajat and Unit of Gunung Salak, participated the PROPER for the recent seven years with a very progressive score. Unit of Kamojang-Darajat has increased 22\% from previous period. In the period of 2013, both Unit of Gunung Salak and Kamojang-Darajat become the top five on Energy Sector, which resulted as Green Category of Beyond Compliance Criteria.

This paper aims to show the success of the company on environmental management of geothermal industry by enhancing community around geothermal operation area. It is also intended to improve environmental compliance of PROPER by encourage public and government participation. 
This objective supported by commitment of corporation to achieve environmental beyond compliance with excellent community development.

Several programs has been successfully held in 2014, taking into account socio-environmental aspects, such as Education of Energy Saving and Climate Change, the Introduction of Municipal Solid and Hazardous Waste in "Kampung Pelag", 25,000 Endemic and Authentic Crops Plantation in Kamojang Forest, and Collaborative Action to Conserve the Cikaro Stream.

\section{MATERIALS AND METHODS}

\section{A. Materials}

Materials for community education about energy efficiency and air pollution aspect required are consists of global warming and electricity crisis videos, drawing equipment for children, miniature of electricity, emission, and also solid waste for simulation session. For education of hazardous and solid waste for Pelag Local Community, several materials required consist of compost equipment set, decayed plants, video of hazardous waste impacts to the human. Both of these programs took place indoor for theoretical lesson learned and outdoor for practical simulation.

Other programs were located outdoor since it was objective focused on biological resource and water conservation. Materials required on endemic crops plantation in Kamojang Forest consists of bamboo stake, water, hoe, sapling (Puspa Schima wallichii), (Manglid - Michelia velutina), (Huru Litsia chinensis), etc. Then the materials required on Cikaro Stream conservation consists of rowing boat, water sampling equipment, dump truck, and scales trash.

\section{B. Methods}

This paper particularly demonstrates the social work of the strategic programs throughout our operations area. It was begun with education to induce society interest, participants in this case, then we taking into account field simulation and evaluated by using questionnaire studies for social aspect. Other programs most likely focused on environmental quality, so that we evaluate the successfulness through some physical condition such as water quality, amount of crops planted, and area of conservation. Also, social impact measures qualitatively by participant testimonials.

Innovation in this paper connected to the strategic programs we've been arranged that covering whole aspects of beyond compliance criteria for geothermal industries, as it referred to PROPER regulation [4]. Every aspect on strategic program, voluntarily this year, contains numerous programs with sustainable and continuous improvement.

\section{ENVIRONMENTAL COMPLIANCE ASSESSMENT (PROPER) OVERVIEW IN INDONESIA}

\section{A. Regulatory Framework}

Industrial sector in Indonesia has increased recently, it makes higher energy demand as reflections in energy sector, whereas the reserve of fossil fuel and mining decreases periodically. In order to maintain energy supply and demand equally, geothermal energy became one of alternative energy solution with clean and renewable behavior.

West Java Province, one of the largest geothermal potential, is very interesting prospect area to develop and maintain energy demand sustainably. At least four energy company and one generation company (owned by PT. Indonesia Power Generation Business Unit of Kamojang) is currently supply the electricity to the Jamali (Java - Madura - Bali) Grid Interconnection System. This energy can replace electricity supply of coal fired power plant and reducing the global warming potential [7].

As geothermal is environmental friendly energy, geothermal industry tends to be dedicated to contribute environmental management goals of Ministry of Environment. PROPER regulated under Minister of Environment Regulation No. 06/ 2013 [5], with geothermal power plant with generating capacity above $55 \mathrm{MW}$ required by rules to take part on environmental compliance aspects.

\section{B. Assessment Step}

Based on Minister of Environment Regulation No. 06/ 2013 [4], assessment of PROPER divided into several steps.

- Preparations step consists of preparation periodical data, lesson learned review, and environmental excellent program.

- Compliance Assessment, a step which energy sector should reporting data and evidences on water contamination reduction, air pollution reduction, hazardous waste management, and environmental permit (EIA, etc.). This step delivers the result into Comply (Blue Category) or Not Comply (Red and Black Category).

- Beyond Compliance Assessment. In this step, only companies that justified as "Comply" can be continue to. There are several aspects assessed, such as Environmental Management System, Energy Efficiency, Hazardous Waste Management, Solid Waste Management, Emission Reduction, Water Conservation, Biodiversity Protection, Community Development, and Executive Summary. This step then delivers the result into "just comply" (back with Blue Category), "beyond comply" (Green Category), and for those company that passed the standard score, will be promoted to the Gold Candidate ("beyond comply with excellency").

\section{Environmental Goals}

As stated previously, GBU Kamojang has reached Beyond Compliance Criteria with Green Category. Geothermal naturally has clustered as compliance with very less impact to the environment and its sustainability is beyond any reasonable doubt [8]. We concerns to improving environmental compliance with strategic plan and excellent program as industries with environmental excellency [9] and community involvement [10]-[12].

\section{RESUlts AND Discussions}

Strategic programs of socio-environmental integrated aspect divided into eight beyond compliance aspects as it 
mentioned previously. There were programs combined from several environmental aspects within social involvement, such as Education of Energy Saving and Climate Change that consist of energy efficiency and air pollution aspect, Education of Hazardous and Solid Waste also crystal clearly that combination between both aspects, and the Collaborative Action to Conserve Cikaro Stream that consists of water conservation and water contamination reduction aspects (in PROPER, it is framed together as Water Conservation beyond compliance aspect). Besides, there also environmental aspect that hasn't combined such as Endemic Crops Plantation, connected to biodiversity protection aspect. Overall programs have been successfully held and possibly can be continued as sustainable program.

\section{A. Education of Energy Saving and Climate Change}

Our company generates electricity by using geothermal as a single source (dry steam for Kamojang - Darajat and water dominated for Gunung Salak). Prior to contribute a large scale of energy efficiency and emission reduction on PROPER, we begin the program with the simplest thing. This is because the majority of communities have limited knowledge [13], [14], so we consider that education method is more relevant. At least $4^{\text {th }}$ and $5^{\text {th }}$ grade of 50 students completed the education; they are students from Integrated Islamic Elementary School Persis (Sekolah Dasar Islam Terpadu - SDIT) Tarogong, Garut - West Java Province. The education at the moment depicted on Fig. 2.

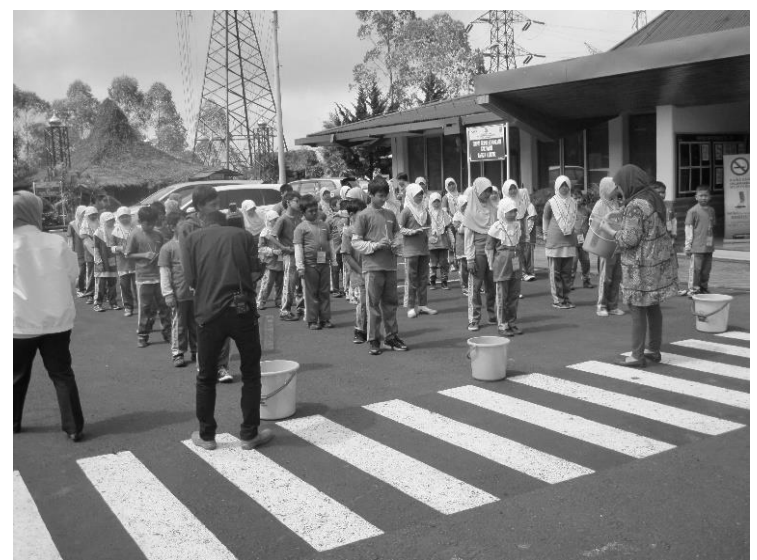

Fig. 2. Outdoor education of energy saving and climate change. Students were simulating greenhouse gases potential that will released to the atmosphere due to unwisely energy use.

This program was collaborated with government, such as Regional Environmental Management Agency of West Java Province and Local Government Agency of Garut. In order to deliver more interactive education, we conduct "Energy Saving - Drawing Competition" in connection with education purpose. As least top six students with the best picture became the champions. Then the drawing competition also depicted on Fig. 3.

We also conducted questionnaire analysis of student's comprehension on related topic. It is about their understanding on global warming potential and its impact to environment. The result concludes that student's comprehension increased $26 \%$ and it also describes the success ratio of this program [15]. The questionnaire result is depicted on Fig. 4.

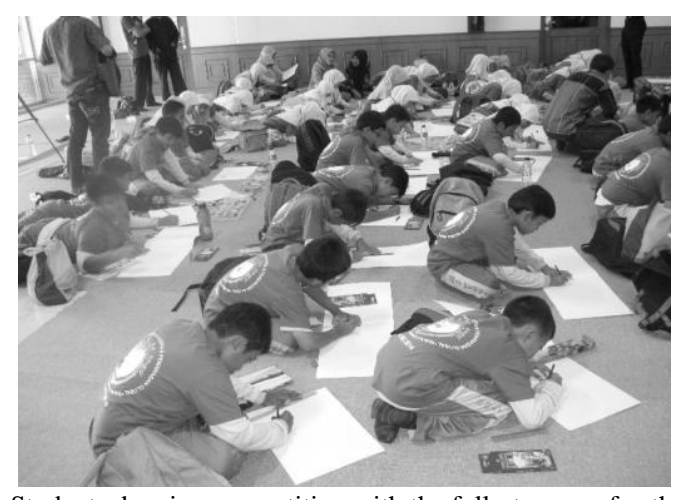

Fig. 3. Students drawing competition with the fullest sense of enthusiasm.

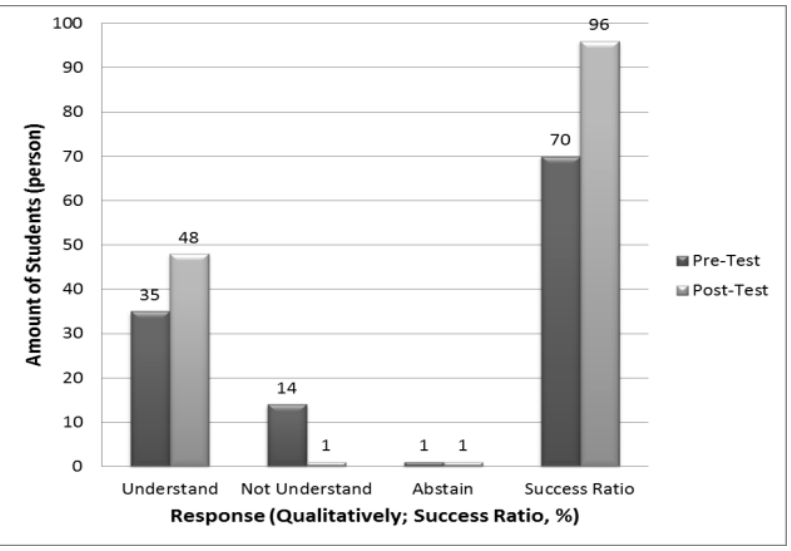

Fig. 4. Questionnaire result on students comprehension (It was measured between students and their response about this education materials, theme and topic, etc.)

\section{B. Education of Municipal Solid and Hazardous Waste for "Pelag Local Community"}

Having concern on generating electricity from geothermal energy endorse us to develop community around. Community Development program together with Corporate Social Responsibility (CSR) gradually empowering society at Pelag Village. By the following of our successful action in Pelag (Pelag location pictured on Fig. 5), we have arranged strategic program to improve livelihood of Pelag Village towards independency on numerous sector, such as education, economic, health and sanity, and also infrastructure.

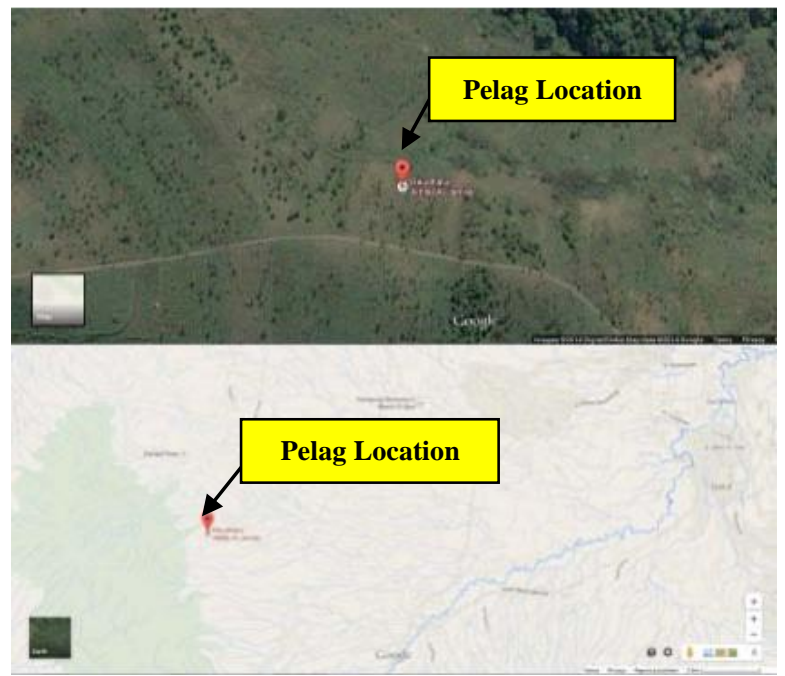

Fig. 5. Pelag location on Google maps. Pelag village located in part of Desa Sukajaya area, Kecamatan Sukaresmi, Kabupaten Garut, West Java Province. The topography is on high elevation and it has area about $13.5 \mathrm{Ha}$ with population about 1,200 people in 2014 . 
One of our starting points to bring Pelag independency is to introduce impact of municipal solid and hazardous waste from daily activity. This program goals is underlined the changing habits and improving environmental awareness. Independency of Pelag also means that community can be motivated to manage their waste, as for organic waste to compost and non-organic waste to be collected and reduced by their own. Community then can be proud of their daily behavior in terms of waste management they figured it out.

Prior to educate community of Pelag, we taking design of education program through field survey. About six families were interviewed to collect information of Pelag pre-condition. Other social activity was also taken into account by considering field observation and documentation. Some of circumstances bring us to take several topics, such as introduction of non-organic waste impact (about waste management with imperfect method and waste disposal is not the preservation of environment), the implementation of waste reduction, and also empowering organic waste handling on site.

About 35 participants joined this education (their age ranging from 14 to 45 years old), whereas our participant estimation was ranging from $20-50$ participants. The participants then depicted on Fig. 6.

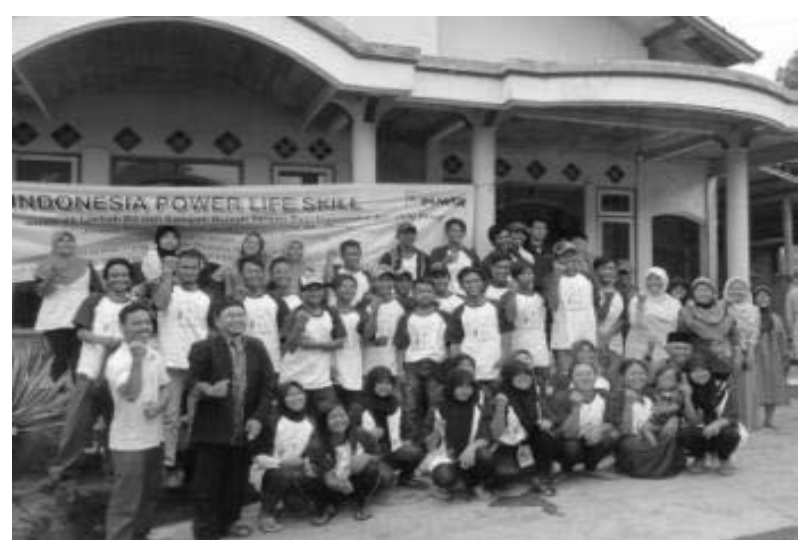

Fig. 6. Community of Pelag village together with PT. Indonesia Power GBU Kamojang and Zero Waste Agent from YPBB Bandung.

Education divided into indoor education that aimed to brainstorms participants prior to simulate the field condition at the outdoor. Outdoor education merely simulates composting from municipal solid waste, considering that there is a lot of organic waste surrounding Pelag Village. Indoor and outdoor education is then depicted on Fig. 7 and Fig. 8.

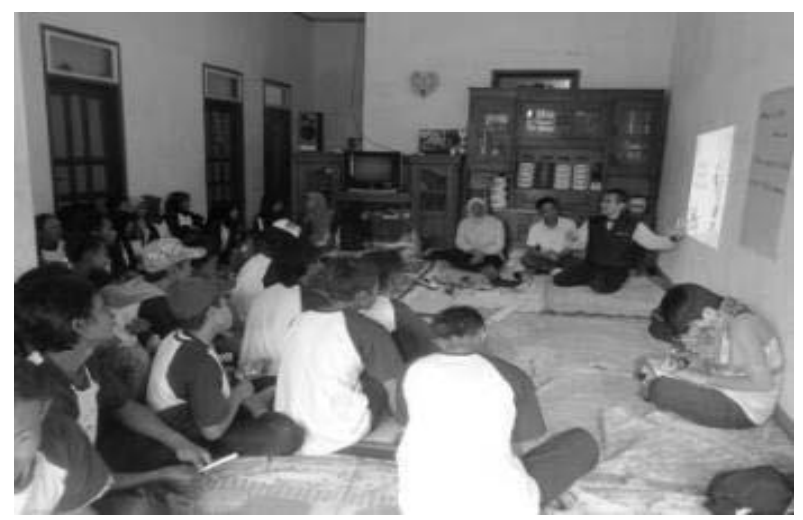

Fig. 7. Common situation of indoor education.

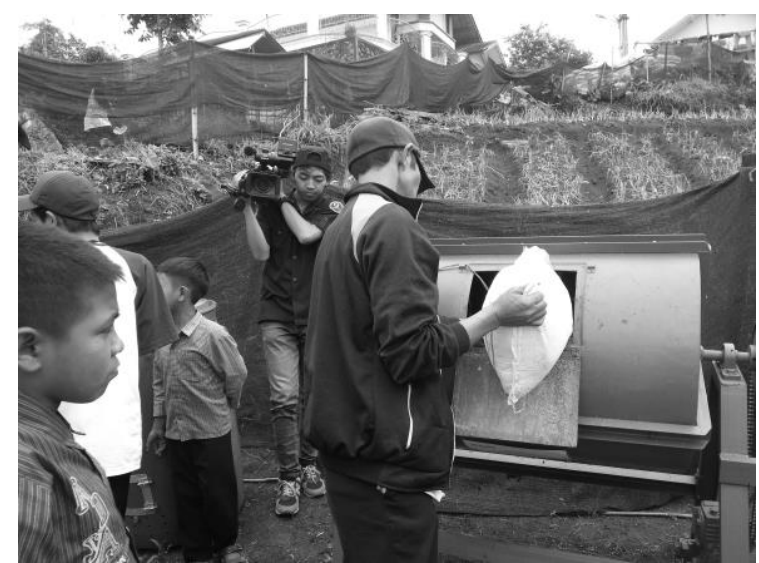

Fig. 8. Situation of outdoor education; where one of participant put the waste into the compost roller.

In order to measure the effectiveness of this education, interview method preferred rather than questionnaire for evaluation due to it considered more effective and viable for society that hold mostly elementary degree only. About 17 percent of participants were interviewed randomly in 15 minutes per each (pre-interview and post-interview). The result is shown in Table I [16].

TABLE I: COMPARISON OF PRE AND POST INTERVIEW

\begin{tabular}{|l|l|}
\hline \multirow{2}{*}{ Pre-Interview } & Generous impact only \\
\cline { 2 - 3 } Post-Interview & $\begin{array}{l}\text { Open burning is not a problem } \\
\text { Impact on un-educated waste handling is more } \\
\text { specific. Participants explained impact with attention } \\
\text { on detail information about kind of diseases caused } \\
\text { by waste and it's destruction to the environment. }\end{array}$ \\
\hline & $\begin{array}{l}\text { Open burning is a problem. Burning waste can } \\
\text { release toxic compound inside waste and harming } \\
\text { environment and society health. }\end{array}$ \\
\hline
\end{tabular}

This program concludes that most of society knowledge increase and successfully stimulate society awareness about waste handling and environmental health. It was also shows during the education, at least 80 percent of participants taking interactive communication in order to learn more about risk and impact of unmanaged solid waste and hazardous waste particularly. It was beyond expectation, that our target of active participants about 50 percent only. They have shown their interest on the importance to keep Pelag Village clean, health, and preserve environment wisely.

\section{25,000 Endemic Crops Plantation in the Kamojang Forest}

GBU Kamojang operates 140 MW Kamojang Geothermal Power Plant, which is located near the Kamojang Forest. We also concern to conserve and protect the biodiversity that is therefore essential in supporting human life and nature [17]. As mentioned earlier that 25,000 endemic crops will be planted in $30 \mathrm{Ha}$ of Kamojang Forest, at the Block of Taman Wisata Alam Kamojang (see Fig. 9).

This program was collaborated between PT. Indonesia Power GBU Kamojang and Conservation of Natural Resources Agency, together with society of Kamojang. It also supported by PT. Indonesia Power Corporation, and Regional Environmental Management Agency of West Java Province and Local Government Agency of Garut. 


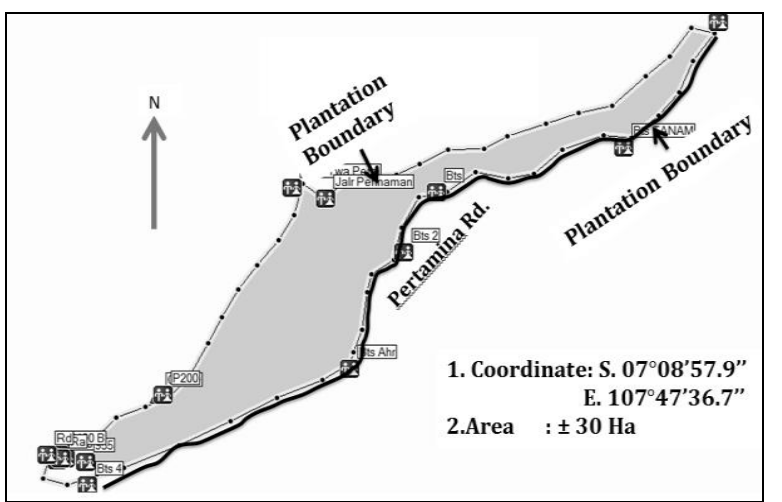

Fig. 9. This figure show Endemic Crops Planstation Area (as it shown in grey area) - located at Block of 48 Kamojang Forest. Plantation Boundary is on Pertamina Road with area about $30 \mathrm{Ha}$.

The endemic crops consist of Puspa (Schima wallichii), Manglid (Michelia velutina), Huru (Litsia chinensis), etc. Prior to conduct this program, we facilitate society around Kamojang area to conduct the nursery process of endemic crops that is originally grown in Kamojang Forest. Endemic seed provided naturally from Kamojang Forest by permitted from local related government that have responsibility to protect and conserve the forest. This nursery has principal objectives that society lives in forest to protect and keep forest green, with authentic crops came from forest and will be planting again for forest authentication.

Since nursery process is one of community empowerment program (work under CSR program) that is supported by PT. Indonesia Power GBU Kamojang, one of the processes of it is then depicted on Fig. 10.

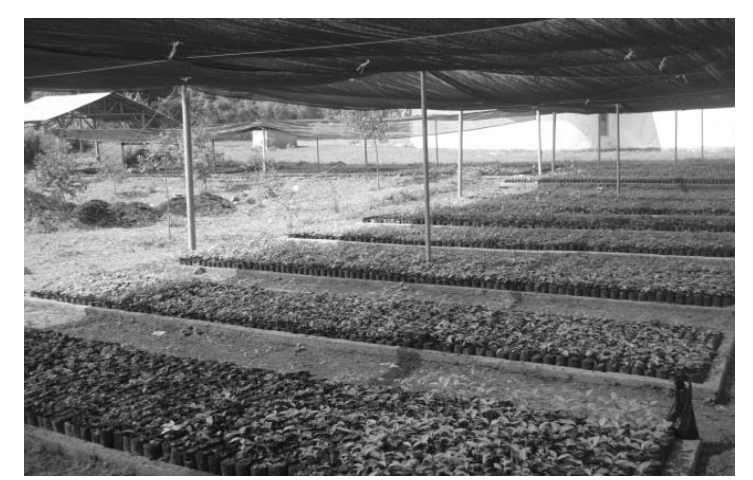

Fig. 10. This picture describes the nursery of endemic crops in Kamojang area. Society empowered by PT. Indonesia Power GBU Kamojang.

This program carried out by the involvement of 150 participants consist of several employee of PT. Indonesia Power GBU Kamojang, local and regional government, local community of Kamojang, etc. At least 5,000 trees have been planted at the moment, and still continuing until 25,000 trees planted. Currently the crops' planting remains less than 10,000 trees and reported monthly [18]. The crops plantation location and activities then pictured on Fig. 11 and Fig. 12.

Upon long term of socio-environmental protection, these endemic crops should be maintained regularly on physical condition such as watering, monitoring of its growth, etc. It is also valuable when we recognize capability to accumulate air emission from geothermal power plant and regional area to reduce greenhouse gases potential as it affected global warming. All of this will worth with further comprehensive calculation and analysis.

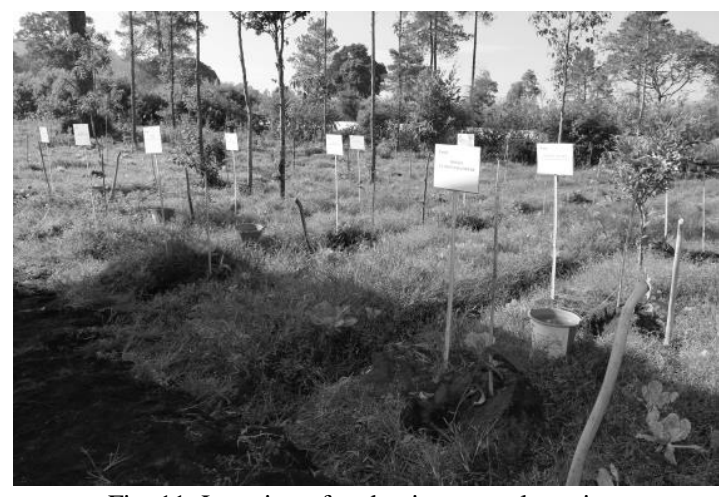

Fig. 11. Location of endemic crops plantation.

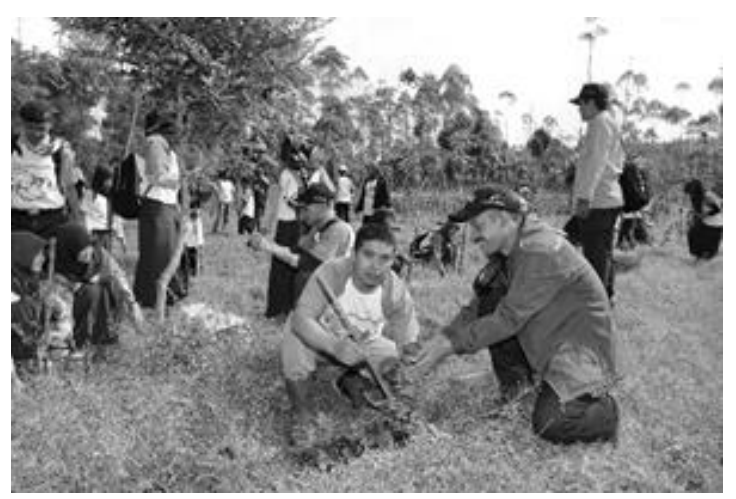

Fig. 12. Plantation of endemic crops.

\section{Collaborative Action to Conserve the Cikaro Stream}

The last socio-environment program that is demonstrated in this paper is conservation of Cikaro Stream that located close to Kamojang Geothermal Power Plant. Even though geothermal electricity generation process does not require make up water (several power plant, such as coal fired power plant use stream water as make up water to cooling down the water residue at Cooling Tower Unit, then processed and disposed it to the stream), Kamojang EIA recommendation was strongly suggest us to monitor the stream water quality. This is monitored both self-monitoring and certified-laboratory-monitoring (PT. Sucofindo) periodically, then quarterly reported to governments and related stakeholders.

The stream condition describes that municipal waste does not exist due to there is not social life around. Nevertheless, dead-aquatic-plant (Teratai: Nymphaea) can trigger eutrophication to the stream. The Cikaro Stream condition is depicted on Fig. 12.

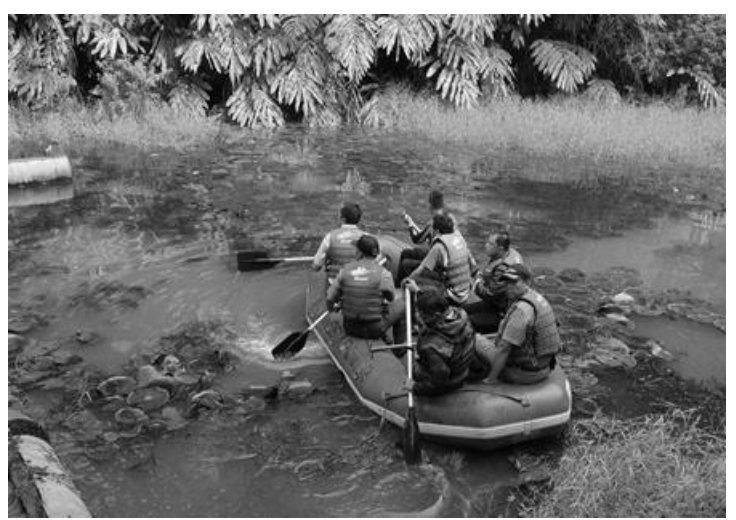

Fig. 12. This picture shows collaborative action at the center part of Cikaro stream, with estimation of volume about 4,000 $\mathrm{m}^{3}(100 \mathrm{~m} \times 10 \mathrm{~m} \times 4 \mathrm{~m})$. 
In order to keep the transpicuous of the stream, about 120 participants were collaborating. They were consisted of PT. Indonesia Power - Generation Business Unit of Kamojang, local community of Kamojang area, Conservation of Natural Resources Agency, Environmental Government, and Sanitation and Landscaping Government Conservation of Natural Resources Agency. About 24 practical students from various reputable universities (ITB, UI, etc.) also joined this program.

Organic waste that accumulated to the stream could trigger the decreasing of water quality and also narrowing the volume of stream itself. This program has been contributed to reduce organic waste about 1.5 ton waste per hour [19], as depicted on Fig. 13.

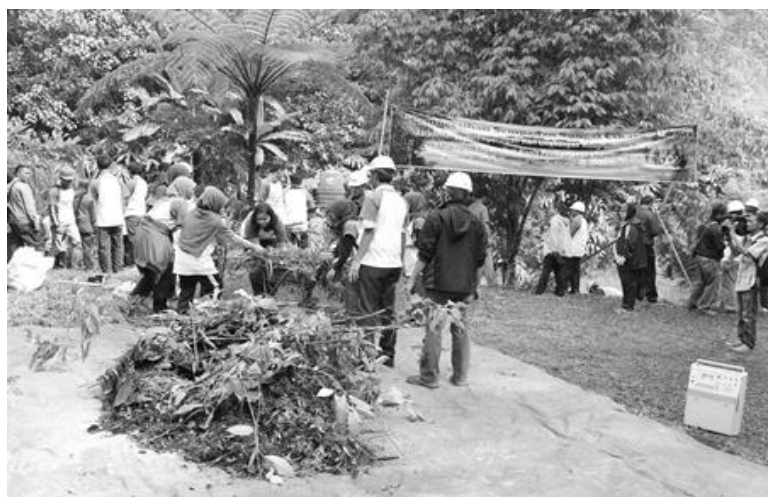

Fig. 13. Organic waste, dominated by decayed aquatic plants.

We also take collaboration with PT. Sucofindo to analyze the stream water quality before and after action. Unfortunately, we regret to announce that the laboratory results have not finished yet, so it was not analyzed further in this paper. On the other hand, we wish to share more about this water conservation effort later.

PROPER, as mentioned earlier, fundamentally aims to announce to every industries about their contribution on environmental protection in Indonesia. The successfulness industries on PROPER deliver as final score of each industry, which is a reflection on industry compliance on environmental management. It is proved by evidence on reporting (as paperwork) and verified to the location not only for industrial area but also to the local community around. The successfulness does not always describe the ongoing program of the year, but the sustainability of program as a result of continuous improvement periodically.

\section{CONCLUSIONS}

The result of this socio-environmental program concludes that education method can improve social perceptions and knowledge about environmental conservation and protection. Social awareness is also a part of society improvement to be more concern with the preservation of environment together with company and local government. Besides that, monitoring and sustainability of program should also be considered in the future.

\section{ACKNOWLEDGMENT}

We would like to thank to the committee for a very cooperative and quick response. Also thanks to PT. Indonesia Power Corporation - Jakarta Office and employee of PT. Indonesia Power - Generation Business Unit of Kamojang for support and sustainable spirit. We also intend our gratitude to our stakeholders, specifically to the local community (Kamojang local community and Pelag Village local community), and governments (Regional Environmental Management Agency of West Java Province, Local Government Agency of Garut, Sanitation and Landscaping Government, etc) for all supports and participation through all of programs we carry out as an initiative action this year.

\section{REFERENCES}

[1] H. G. Sequeira, "Environmental management in geothermal development: case history for Costa Rica," in Proc. World Geothermal Congress 2010, Bali, Indonesia, 2010, pp. 1-6.

[2] N. Zepeda and J. A. Rodriguez, "Socially responsible geothermal development in El Salvador," in Proc. World Geothermal Congress 2005, Antalya, Turkey, 2005, pp. 1-3.

[3] U. Slamet and D. G. Moelyono, "Maximizing community benefits and minimizing environmental impacts in the Gunung Salak geothermal project, Indonesia," in Proc. World Geothermal Congress 2000, Jyushu - Tohoku, Japan, 2000, pp. 1-5.

[4] G. N. Wetang'ula, "Public participation in environmental and socioeconomic considerations for proposed 2.5 MW pilot Eburru geothermal power project, Kenya," in Proc. World Geothermal Congress 2010, Bali, Indonesia, 2010, pp. 1-11.

[5] Peraturan Menteri Lingkungan Hidup Republik Indonesia No. 06 Tahun 2013 Tentang Program Penilaian Peringkat Kinerja Perusahaan dalam Pengelolaan Lingkungan Hidup, Regulatory Framework on Environmental Compliance in Indonesia, Jakarta, Indonesia, 2013, pp. 1-7.

[6] M. Agani, K. Rozaq, and Z. I. Bachrun, "Construction and operation of Kamojang Unit 4, the first commercial geothermal power plant built, owned and operated by PT. Pertamina Geothermal Energy," in Proc. World Geothermal Congress 2010, Bali, Indonesia, 2010, pp. 1-7.

[7] K. Yasukawa, T. Noda, H. Muraoka, M. Adachi, I. Matsunaga, and S. Ehara, "Long-Term prospects of geothermal energy uses and their environmental effects in Japan," in Proc. World Geothermal Congress 2010, Bali, Indonesia, 2010, pp. 1-4.

[8] R. Bonciani, A. Lenzi, F. Luperini, and F. Sabatelli, "Geothermal power plants in Italy: increasing the environmental compliance," in Proc. European Geothermal Congress 2013, Pisa, Italy, 2013, pp. $1-5$.

[9] D. Permatasari and D. Gumbira, "Environmental Management Strategic Program of PT. Indonesia Power Generation Business Unit of Kamojang,” Internal Report, Kamojang, Indonesia, pp. 1-8, 2013.

[10] D. Permatasari and D. Gumbira, "Community Development Strategic Program of PT. Indonesia Power Generation Business Unit of Kamojang," Internal Report, Kamojang, Indonesia, pp. 1-4, 2013.

[11] G. N. Wetang'ula, "Public participation in environmental and socioeconomic considerations for proposed 2.5 MW Pilot Eburru Geothermal Power Project, Kenya," in Proc. World Geothermal Congress 2010, Bali, Indonesia, 2010, pp. 1-11.

[12] R. Musembi, "Corporate Social Responsibility (CSR) in geothermal development: the case of the Geothermal Development Company (GDC), Kenya," in Proc. Third East African Rift Geothemal Conference, Djibouti, 2010, pp. 1-6.

[13] L. Romanach and S. C. Cornish, "Societal acceptance of geothermal energy technology in Australia: media portrayals and public perceptions," in Proc. Australian Geothermal Energy Conferences 2013, Brisbane, Australia, 2013, pp. 1-3.

[14] H. G. Sequeira, "Environmental management in geothermal development: case history for Costa Rica," in Proc. World Geothermal Congress 2010, Bali, Indonesia, 2010, pp. 1-6.

[15] D. Permatasari, Muldjianto, and A. Sumarna, "Education of energy saving and climate change for SDIT Persis Tarogong, Garut," Indonesia: Kamojang, pp. 1-10, Internal Report, 2014.

[16] A. Nurwahidin, R. Sunaryadi, J. Fam, M. Arif, and E. Sutisna, "Education of hazardous and solid waste for Pelag local community, Garut," Internal Report, Bandung, Indonesia, pp. 1-12, 2014.

[17] T. M. Mutia, "Biodiversity conservation and geothermal development," in Proc. Third East African Rift Geothemal Conference, Djibouti, 2010, pp. 1-8. 
[18] A. Sumarna, I. Rosdiana, and D. Permatasari, “25,000 Endemic Crops Plantation in the Kamojang Forest, Kamojang," Internal Report, Indonesia: Kamojang, pp. 1-5, 2014.

[19] D. Permatasari and Suherman, "Collaborative action to conserve the Cikaro Stream, Kamojang," Internal Report, Kamojang, Indonesia, pp. 1-8, 2014.

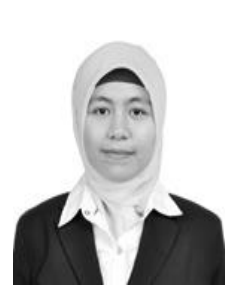

Dewi Permatasari was born in Bandung, West Java, Indonesia. Dewi was the best graduate in her bachelor degree study under Department of Environmental Engineering, Institut Teknologi Sepuluh Nopember, Surabaya. She continued her study on geothermal engineering in Institut Teknologi Bandung.

She started her career when she was in college with various project about environment study. She joined the project about solid waste reduction in Surabaya, which was supported by Unilever Indonesia. She also has had some research on wastewater advanced treatment. She is very excellent on environmental impact assessment; she is a freelancer on it. The EIA project was Sungai Penuh and Hululais Geothermal Project, owned by PT. Pertamina Geothermal Energy. In geothermal engineering of ITB she became a trainer about geothermal environment for industries, such as PT. Pertamina Geothermal Energy (BPS Pertamina), Chevron, Star Energy, and several lecturer from reputable university (USAID Indonesia - ITB - Star Energy -
USC Training for Trainers). She also joined her lecturer on assistance of feasibility study of Kamojang Unit V development, review of EIA document for Karaha Bodas Unit II \& III, also owned by PT. Pertamina. Since August 2013, she joined PT. Indonesia Power - GBU of Kamojang as a professional environment and CSR advisor, worked under supervision of management.

Permatasari had joined ITB International Geothermal Workshop committee on 2012 and 2013.

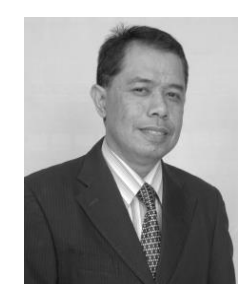

Eko Yuniarto was born in Bandung, West Java, Indonesia, on June $29^{\text {th }}, 1970$. In 1994, Eko earned his bachelor degree from mechanical engineering, Institut Teknologi Bandung, West Java Province, Indonesia. $\mathrm{He}$ has joined PT. Indonesia Power for more than 18 years. In May 2014, he became the general manager of PT. Indonesia Power-Generation Business Unit of Kamojang. His previous positions were commercial senior executive (from November 2011) and project feasibility expert (from September 2010) at PT. Indonesia Power Corporation. He also has experience on leading geothermal power plant operation as a manager of Gunung Salak Geothermal Power Plant Sub-Unit of PT. Indonesia Power - Generation Business Unit of Kamojang (on April 2006). He has abundant training experience on Management, Operation, etc.

Ir. Yuniarto registered as a IICD associate member on June 2012. 